\title{
Spectroscopic Determination of Optimal Hydration Time of Zircon Surface
}

\section{Eduardo Ordóñez-Regil, ${ }^{1 *}$ Genoveva García-Rosales ${ }^{1,2}$ and Nidia García-González ${ }^{3}$}

${ }^{1}$ Departamento de Química., Instituto Nacional de Investigaciones Nucleares. Carretera México-Toluca S/N, km. 36.5. La Marquesa, Ocoyoacac, México eduardo.ordonez@inin.gob.mx

2 División de Estudios de Post-Grado, Instituto Tecnológico de Toluca. Ex Rancho la Virgen s/n, Metepec, Estado de México, México.

${ }^{3}$ Facultad de Química, Universidad Autónoma del Estado de México. Av. C. Colón y Av. Tollocan, Toluca, Estado de México, México

Received November 10, 2009; Accepted May 7, 2010

\begin{abstract}
When a mineral surface is immersed in an aqueous solution, it develops an electric charge produced by the amphoteric dissociation of hydroxyl groups created by the hydration of the solid surface. This is one influential surface property. The complete hydration process takes a time which is specific for each mineral species. The knowledge of the aqueous solution contact time for complete surface hydration is mandatory for further surface phenomena studies. This study deals with the optimal hydration time of the raw zircon $\left(\mathrm{ZrSiO}_{4}\right)$ surface comparing the classical potentiometric titrations with a fluorescence spectroscopy technique. The latter is easy and reliable as it demands only one sample batch to determine the optimal time to ensure a total hydration of the zircon surface. The analytical results of neutron activation analysis (NAA) showed the presence of trace quantities of $\mathrm{Dy}^{3+}, \mathrm{Eu}^{3+}$ and $\mathrm{Er}^{3}$ in the bulk of zircon. The $\mathrm{Dy}^{3+}$ is structured in the zircon crystalline lattice and undergoes the same chemical reactions as zircon. Furthermore, the $\mathrm{Dy}^{3+}$ has a good fluorescent response whose intensity is enhanced by hydration molecules. The results show that, according to the potentiometric analysis, the hydration process for each batch (at least 8 sample batches) takes around $2 \mathrm{~h}$, while the spectrometric method indicates only $5 \mathrm{~min}$ from only one batch. Both methods showed that the zircon surface have a $16 \mathrm{~h}$ optimal hydration time.
\end{abstract}

Keywords: Hydration, Dysprosium, Zircon, Fluorescence.

\section{Introduction}

In the area of depolluting processes [1-3] and in that of the migration of heavy metals ions in the geosphere [4,5], the interface mineral/water phenomena are of great importance. It is well-known that the mineral surfaces play an important role in controlling the trace element chemistry of natural waters [6-8]. The characterization of the interactions between metal ions and solids in aqueous suspension has been investigated especially at the oxide/solution interface [9]. These interactions depend mainly on physicochemical parameters such as redox potential, ionic strength and suspension $\mathrm{pH}$, related to the variation of the electrical charges developed in the surface $[10,11]$. The solid surface in an aqueous medium reacts with the water molecule giving hydroxyl groups and developing amphoteric species. This phenomenon depends on the $\mathrm{pH}$ and on the ionic strength of the solution [12]. The surface hydroxyl groups constitute ionizable functional groups which determine the amphoteric behavior of the substrate. Many efforts
Resumen. Los minerales que son inmersos en solución acuosa, desarrollan una carga eléctrica, producida por la aparición de la disociación anfotérica de los grupos hidroxilo formados en superficie. Esta propiedad es específica para cada mineral y la determinación del tiempo de hidratación es fundamental para realizar posteriores estudios de sorción en la interfase sólido/líquido. En este estudio se determinó el tiempo óptimo de hidratación del circón $\left(\mathrm{ZrSiO}_{4}\right)$, comparando la técnica clásica por titulación potenciométrica con la técnica de fluorescencia a diferentes tiempos. La técnica de fluorescencia fue desarrollada gracias a las impurezas de tierras raras que son contenidas en cantidades traza en los minerales de circón. El análisis por activación neutrónica mostró que las impurezas contenidas en este lote de circón eran principalmente el $\mathrm{Dy}^{3+}, \mathrm{Eu}^{3+}$ y el $\mathrm{Er}^{3+}$. $\mathrm{El} \mathrm{Dy}^{3+}$ tiene una buena respuesta fluorescente que se incrementa con las moléculas de agua a medida que este elemento se hidrata. Los resultados mostraron que el método potenciométrico es largo y tedioso, pues se requiere un lote por cada tiempo en estudio y toma alrededor de $2 \mathrm{~h}$ el análisis, en tanto que el método espectroscópico requiere de una sola muestra que se analiza puntualmente pasado el tiempo requerido, esto sólo toma 5 min, después del cual se continua con el proceso de hidratación. Ámbos métodos mostraron que la superficie del circón requiere de 16 h para alcanzar el tiempo óptimo de hidratación.

Palabras clave: Hidratación, disprosio, circón, fluorescencia.

have contributed to the study of materials with potential use in the construction of sorption barriers able to take up radioactive isotopes from possible leakages in the repositories. In this way, mineral oxides have been chosen as candidates for sorption barriers [13]. Abundant Zircon $\left(\mathrm{ZrSiO}_{4}\right)$ mineral has been found in some beach sands of Mexico, with the ability to develop surface amphoteric species and with the property to retain heavy elements in its hydroxylated surface $[14,15]$. The hydration process of the surface depends on the contact time, $\mathrm{pH}$ and ionic strength of the suspension solid/water. The time in which this process is carried out is an essential factor to measure the total site density developed in the surface. This time has been usually determined by potentiometric measurements [16]. Some impurities mainly composed by heavy elements in very small amounts are present in the samples of natural zircon $[17,18]$. Then, it is not surprising to found that some impurities contain rare earth elements, which are found normally in igneous or metamorphic zircon, overlapped in your structure during its geological formation. Yet, the element 
nature and its content are not constant throughout the samples [19]. In this study, a zircon sample batch was obtained from beach sand after acidic lixiviation where only some rare earths remained in the bulk because they were imbibed into the crystalline lattice. Thus, the presence of $\mathrm{Dy}^{3+}$ is almost normal in the material [20]. Thus, the Zircon/Dy optimal time hydration has been determined by two methods: a) potentiometric titration and b) fluorescence spectroscopy. The first method uses a series of batches of suspension, whose titration requires some process time. The other one, based on fluorescence phenomena, demands only one batch which is analyzed immediately after each chosen time. Zircon $\left(\mathrm{ZrSiO}_{4}\right)$ exhibits trace amounts of lanthanides which have fluorescent properties [21]. The presence of this rare earth allowed a luminescence study aimed to determine the hydration time of $\mathrm{ZrSiO}_{4}$. The luminescence spectroscopy of $\operatorname{Ln}(\mathrm{III})$ ions is characterised by very narrow emission bands and a long decay time. This is an important technique in the study of analytical and photophysical aspects of the lanthanide chemistry [22,23]. $\mathrm{Ln}$ (III) presents characteristic luminescence spectra in the visible and the near-IR region resulting from electronic transitions among $4 \mathrm{f}$ levels [24]. These transitions give rise to atomic-like spectral lines.

\section{Results and discussion}

\section{Elemental analysis ( $N A A)$}

A Neutron Activation Analysis (NAA) was calibrated over reference zircon samples in order to evaluate the purity of the mineral. Only trace elements were found in the studied material. The elements detected by this technique were $\mathrm{Dy}^{3+} 74 \pm 1$ $\mu \mathrm{g} / \mathrm{g}, \mathrm{Eu}^{3+} 1.40 \pm 0.1 \mu \mathrm{g} / \mathrm{g}$ and $\mathrm{Er}^{3+} 62 \pm 0.1 \mu \mathrm{g} / \mathrm{g}$ : rare earths are often linked to zircon structure. Furthermore, in granitic and some metamorphic rocks as zircon, some trace elements like lanthanides or actinides are normally present on specific locations of the lattice $[25,26]$.

\section{Surface hydration process}

The water on a solid interface follows a two step mechanism during the hydration process. The first one is the hydration of $\mathrm{Si}$ and $\mathrm{Zr}$ atoms without reaction, bounded only by Van der Waals forces. (Reaction 1, a). The second step corresponds to a dissociative mechanism of water, where $\mathrm{H}$ groups of water can be linked to negative $\mathrm{SiO}$ or $\mathrm{ZrO}$ radicals from singly protonated atoms while the remaining $\mathrm{OH}$ atom is transferred to $\mathrm{Si}$ or $\mathrm{Zr}$ positively charged radicals (Reaction 1, b). [27]

The amphoteric stabilisation of species starts after the hydroxylation process. These hydroxylated species are $\mathrm{pH}$ dependent and they adopt positive, neutral or negative forms (Reaction 2). Given the structure of $\mathrm{ZrSiO}_{4}$, two active endings $\equiv \mathrm{Zr}$ and $\equiv \mathrm{Si}$ are present. Thus, the surface of the material can form two different kinds of molecules, but resulting in similar amphoteric species: $\equiv \mathrm{Zr}-\mathrm{OH}$ and $\equiv \mathrm{Si}-\mathrm{OH}[28,29]$.

As $\mathrm{Dy}^{3+}$ is a heavy ion, it is able to substitute some $\equiv \mathrm{Zr}$ and $\equiv \mathrm{Si}$ on the surface allowing the production of $\equiv \mathrm{Dy}$ species that will follow all the reactions described above.

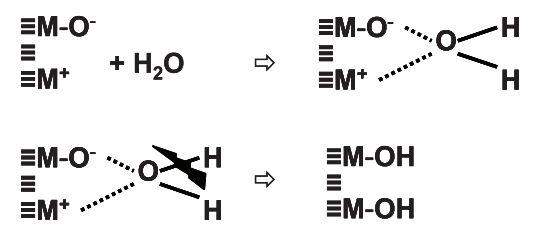

Reaction 1. $\equiv \mathrm{M},=\mathrm{Zr}$ or Si in the bulk.

$$
\begin{aligned}
& \equiv \mathrm{MOH}+\mathrm{H}^{+} \Leftrightarrow \mathrm{MOH}_{2}^{+} \\
& \equiv \mathrm{MOH} \Leftrightarrow \mathrm{MO}^{-}+\mathrm{H}^{+}
\end{aligned}
$$

Reaction 2. $\equiv \mathrm{M},=\mathrm{Zr}$ or $\mathrm{Si}$ in the bulk

\section{Potentiometric titration}

Figure 1 shows the titration plots, where an increasing consumption of titrant solution with the hydration time is observed, suggesting that the hydration time required to attain equilibrium between the solid and the aqueous solution was approximately $16 \mathrm{~h}$. After $24 \mathrm{~h}$, the titration solution had diminished because the environmental carbonate reacts with hydroxylated groups on the surface. The plot also indicates that the hydration process begins in the first minutes of contact time. As the time elapses, more hydroxyl groups are formed on the surface until no more sites are available to the hydroxyl formation and no more titration solution is necessary. At this point, it is considered that stabilisation has been reached [30].

\section{Fluorescence measurements}

Given the three peaks observed on the excitation spectrum (Figure $2 \mathrm{a})$ the $390 \mathrm{~nm}$ one $\left(4 \mathrm{~K}_{17 / 2}\right.$ state) was used, due to its low interference with the quartz cell. The emission spectra were recorded in the region between $425 \mathrm{~nm}$ and $750 \mathrm{~nm}$ at a $390 \mathrm{~nm}$ wavelength. The resulting spectrum exhibits three intense bands at 486, 584 and $698 \pm 0.5 \mathrm{~nm}$ (Figure 2b).

These emission signals were related, as usual, to the $\mathrm{f}-\mathrm{f}$ transitions of the $\mathrm{Dy}^{3+}$ ion $[31,32]$, namely ${ }^{4} \mathrm{~F}_{9} \rightarrow{ }^{6} \mathrm{H}_{15 / 2}(486$ $\mathrm{nm}$, blue colour), ${ }^{4} \mathrm{~F}_{9} \rightarrow{ }^{6} \mathrm{H}_{13 / 2}(584 \mathrm{~nm}$, yellow colour) and ${ }^{4} \mathrm{~F}_{9} \rightarrow{ }^{6} \mathrm{H}_{11 / 2}(698 \mathrm{~nm}$, red colour $)$ transitions. The second transition was followed by a study of the hydration process at different contact time.

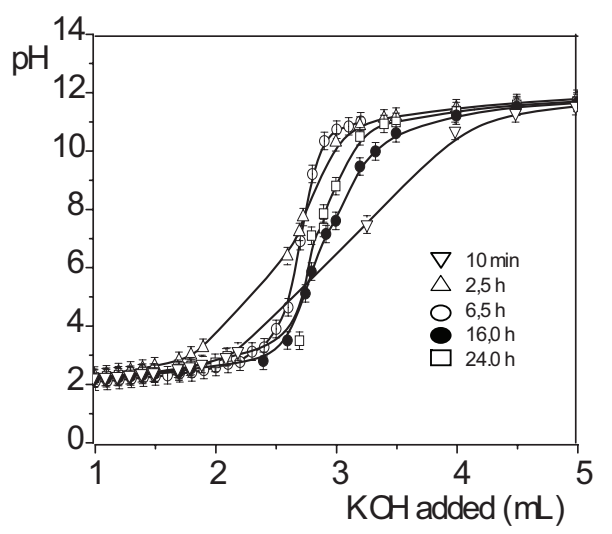

Fig. 1. Titration plots of suspension at different hydration times. 


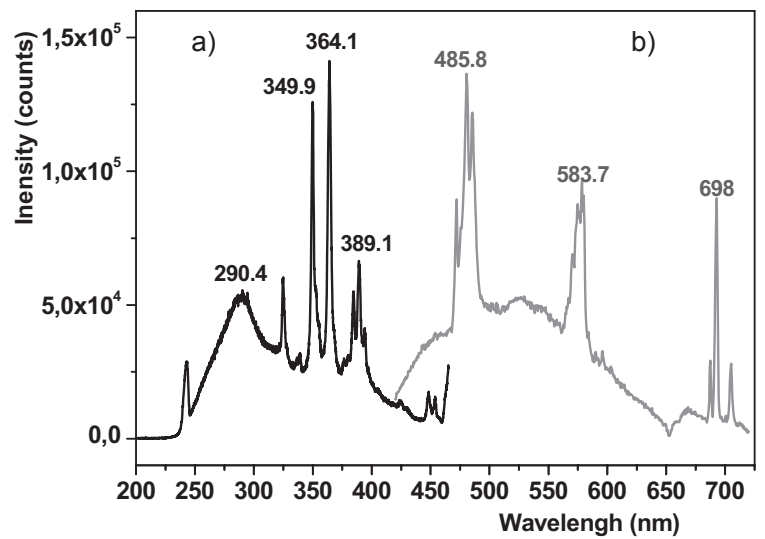

Fig. 2. Fluorescence spectra. a) excitation and b) emission bands.

Some effects of the hydration time on zircon are presented in Figure 3, where a sealed sample was studied at different contact times: $10 \mathrm{~min}, 2$, 6, 16, 24, 48 h by fluorescence. The Figure depicts the intensity of DyO formed on the surface according to the contact time. The signal intensity increases with the sample hydration time until $16 \mathrm{~h}$. After this time, the luminescence intensity decreases. This effect is the result of the presence of $\mathrm{CO}_{2}$ dissolved in the solution, which is sorbed on the mineral surface, leading to a reduction of the hydroxylated groups.

The $\mathrm{Dy}^{3+}$ produces a specific emission spectrum [33-35], under appropriate illumination. Furthermore, it has been observed that the fluorescence signals are more intense for $\mathrm{DyOH}$ species and that the increases of the hydroxylated groups can result in more intense emission signals, until hydration is complete and a steady signal is obtained despite the contact time increment.

\section{Conclusion}

Two methods to determine the optimal hydration time on a mineral solid surface have been compared. In accordance with the results obtained by titration and luminescence, both

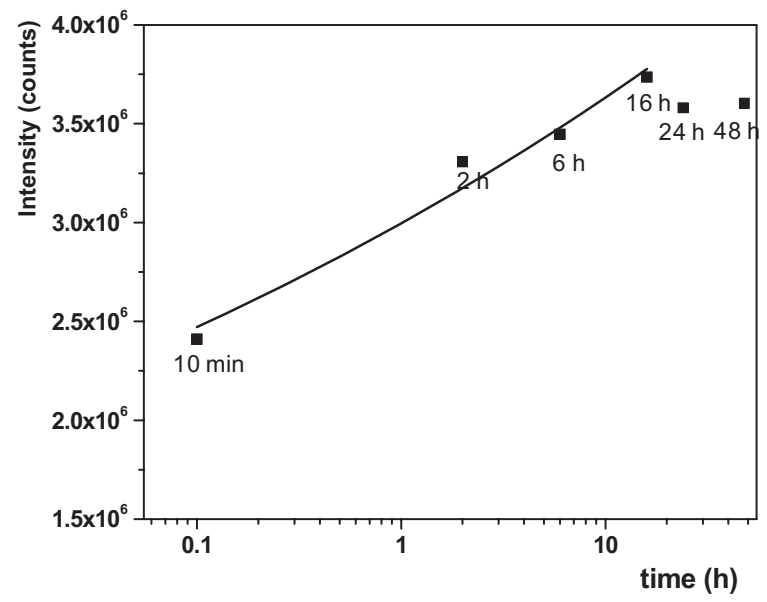

Fig. 3. Graph of contact time $v s$ intensity. methods have proved to be useful to this purpose. The optimal hydration time for zircon/Dy is $16 \mathrm{~h}$, according to both methods. This can be attributed to the complete reaction of density sites on the surface of the material, which are the same for $\mathrm{ZrO}$ and DyO.

The results from this research indicate that fluorescence spectroscopy and the conventional potentiometric titration can be used satisfactorily in determining the optimal point of hydration time on a mineral surface.

\section{Materials and methods}

\section{Elemental analysis}

A sample of natural zircon sand, extracted from beach sand originated in Baja California Sur, Mexico, was purified with nitric acid (in order to avoid calcareous materials and hydrofluoric acid to destroy any siliceous minerals) and then heated at $800^{\circ}$ for $6 \mathrm{~h}$. Three $100 \mathrm{mg}$ samples of the zircon were irradiated at $1 \times 10^{13}$ neutrons $/ \mathrm{s} . \mathrm{cm}^{2}$ flux for one $5 \mathrm{~min}$ period in the pneumatic system (SINCA) of the Triga Mark III Reactor (TMIIIR) of the Instituto Nacional de Investigaciones Nucleares of Mexico. After $48 \mathrm{~h}$, the activity of the samples was counted during $10 \mathrm{~min}$ by means of a hyper pure germanium detector, previously calibrated by $\mathrm{Na}, \mathrm{Cs}$ and $\mathrm{Co}$ gamma energy spectra, and recorded in Maestro2 software.

\subsection{Potentiometric titrations}

In order to assess the optimal hydration time of the Zircon $\left(\mathrm{ZrSiO}_{4}\right)$ surface, potentiometric titrations were performed at $25^{\circ} \mathrm{C}$. The time required to reach equilibrium between the powdered solid and the aqueous medium (hydration time) was determinate on different suspensions containing the same powdered sample mass $(2 \mathrm{~g})$ immersed in $30 \mathrm{~mL}$ of $0.5 \mathrm{M} \mathrm{KNO}_{3}$ solution and shaken during several hydration times (10 min, $2.5 \mathrm{~h}, 6.5,16$ and $24 \mathrm{~h}$ ), the suspensions obtained were acidified with $0.1 \mathrm{M} \mathrm{HNO}_{3}$ to a $\mathrm{pH}$ close to 2 . The titrations were carried by adding incremental base volumes using $0.1 \mathrm{M} \mathrm{KOH}$, for times in accordance with $\mathrm{pH}$ equilibration recording the $\mathrm{pH}$ after each addition using an $\mathrm{Ag} / \mathrm{AgCl}$ electrode. The precision of the measured $\mathrm{pH}$ values was estimated to be \pm 0.2 units. During the experiment, the suspensions were continuously stirred as to prevent settling. All the solutions were prepared using deionized water and high purity reagents.

\section{Fluorescence measurements}

Experiments were carried out over one batch of $\mathrm{ZrSiO}_{4} / \mathrm{KNO}_{3}$ $0.5 \mathrm{M}$ suspension at different contact times (10 min, 2, 6, 16, $24,48 \mathrm{~h}$ ). The hydration level was followed by hydroxylation of some $\mathrm{ZrO}$ or $\mathrm{SiO}$ sites formed continuously along the contact time. Lanthanides, usually found in natural minerals, can be part of the crystallographic lattice. They follow the same fate that the $\mathrm{ZrO}$ or $\mathrm{SiO}$ species formed over the surfaces. 
Among lanthanides content in the zircon, traces of $\mathrm{Dy}^{3+}$ were found in our samples.

In the present study, the fluorescence $\mathrm{Dy}^{3+}$ signal produced by an excitation beam has been recorded as an emission spectrum. The fluorescence emissions were carried out at room temperature using a tunable Fluorolog 3-22 Jobin-Yvon Horiba Continuum Xenon source with a $390 \pm 0.5 \mathrm{~nm}$ excitation wavelength. Measurements were carried out using a quartz cell, covering an emission range from 420 to $750 \mathrm{~nm}$ through a $5 \mathrm{~nm}$ optical slit. Dy/zircon powder was used as a blank.

\section{References}

1. Browski, A. Adv. Colloid Interface Sci. 1998, 93, 135.

2. Viel, P.; Dubois, L.; Lyskawa, J.; Salle, M.; Palacin, S. Applied Surf. Sci. 2007, 253, 3263-3269.

3. Saiano, F.; Ciofaloa, M.; Cacciola, S. O.; Ramirez, S. Water Res. 2005, 39, 2273-2280.

4. Arnold, T.; Zorn, T.; Bernhardt, G.; Nitche, H. Chem. Geol. 1998, $151,129$.

5. Morrison, S. J.; Tripathi,V. S.; Spangler, R. R. J. Contam. Hydrol. 1995, 17, 129.

6. Sposito, G. Chemical Equilibria and Kinetic in Soils, Oxford University Press, Oxford 1994.

7. Gräfe, M.; Beattie, D. A.; Smith, E.; Skinner, W. M.; Singh, B. Colloid Interface Sci. 2008, 322, 399-413.

8. Nore'n, K.; Persson, P. Geoch. Cosmochim. 2007, 71, 5717-5730.

9. García-Rosales, G.; Drot, R.; Mercier-Bion, F.; Lagarde, G.; Simoni, E. J. Colloid Interface Sci. 2009, 333, 104-113.

10. Chvedov, D.; Logan, E. L. B. Colloids Surfac. Phys. 2004, 240, 211-223.

11. Kyung, T. O.; Dongin, K.; Hyeon, H. Y.; Yong, S. A.; Eun, S. L. J. Pharm. 2009, 376, 134-140.

12. Ordoñez-Regil, E.; Drot, R.; Simoni, E. Langmuir 2002, 18, 7977.

13. Galunin, E. D.; Alba, M.; Avilés, M. A.; Santos, M. J.; Vidal, M. J. Hazardous Mater, 2009, 172, 1198-1205.

14. Hanchar, J. M.; Finch, R. J.; Hoskin, P. W. O. Am. Mineral 2001, $86,667-680$.
15. Fenter, P.; Sturchio, N. C. Surface Sci. 2004, 77, 171-258.

16. García-Rosales, G.; Ordóñez-Regil, E.; Drot. R.; Pérez, M. Rev. Intern. Inf. Tecnol. 2004, 15, 39-45.

17. Mungchamnankit, A.; Limsuwan, P.; Thongcham, K.; Meejoo, S. J. Mag. Mag. Mater. 2008, 320, 479-482.

18. Nasdala, L.; Hanchar, J. M.; Kronz, A.; Whitehouse, M. J. Chem. Geol. 2005, 220, 83-103.

19. Whitehouse, M. J., Geochronology: linking the isotopic record with petrology and textures. Ed. Geological Society of London, 2003, p 50.

20. Xia, Q.-X.; Zheng, Y.-F., Hu, Z. Lithos 2010, 114, 385-412.

21. Siyanbola, W. O.; Fasasi, A. Y.; Funtua, I. I.; Fasasi, M. K.; Tubosun, I. A.; Pelemo, D. A.; Adesiyan, T. A. Nuclear Inst. Met. Physics Res. B. 2005, 239, 426-432.

22. Gaft, M.; Panczer, G.; Reisfeld, R.; Shinno, I. J. Alloys Compd. 2000, 300-301, 267-274.

23. Lis, S. J. Alloy Compd. 2002, 341, 45-50.

24. Gaft, M.; Panczer, G.; Reisfeld, R.; Shinno, I.; Champagnon, B.; Boulon, G. J. Lumin. 2000, 87-89, 1032-1035.

25. Nasdala, L.; Hanchar, J. M.; Rhede, D.; Kennedy, A. K.; Váczi, T. Chem. Geology 2010, 269, 290-300.

26. Lang, M.; Zhang, F.; Lian, J.; Trautmann, C.; Neumann, R.; Ewing, R.C. Earth Planetary Sci. 2008, 269, 291-295.

27. Perron, H.; Vandenborre, J.; Domain, C.; Drot, R.; Roques, J.; Simoni, E.; Ehrhardt, J.-J.; Catalette, H. Surf. Sci. 2007, 601, 518-527.

28. Lomenech, C.; Simoni, E.; Drot, R.; Ehrhardt J.-J.; Mielczarski, J. J. Colloid Interf. Sci. 2003, 261, 221-232.

29. Dzombak, D. A.; Morel, F. M. M. Surface Complexation Modeling: Hydrous Ferric Oxide, Wiley \& Sons Eds, New York, 1990.

30. Finck, N.; Drot, R.; Mercier-Bion, F.; Simoni, E.; Catalette, H. J. Colloid Interf. Sci. 2007, 312, 230-236.

31. Dai, P.-L.; Tsai, B.-S.; Tsai, Y.-Y.; Chen, H.-L.; Fang, T.-H.; Liao, K.-H.; Chang, Y.-S. Optical Mater. 2009, 32, 392-397.

32. Tsai, Y.-Y.; Chen, H.-L.; Fang, T.-H.; Liao, K.-H.; Chang, Y.-S. Optical Mater. 2009, 32, 392-397.

33. Hussin, R.; Hamdan, S.; Fazliana, D. N.; Halim, A.; Shawal Husin, M. Mater.Chem.Physics, 2010, 121, 37-41.

34. Wen-Xian, L.; Yu-Shan, Z.; Xiao-Jun, S.; Wen-Juan, C.; Tie, R.; Xiao-Yan, S. J. Lumin. 2010, in press.

35. Zhao, J.; Huang, L.; Wang, Y.; Zhu J. Physica B: Cond. Matter 2005, 362, 103-107. 